\title{
Birth and death: infant burials from Vlasac and Lepenski Vir
}

\author{
Dušan Borići \& Sofija Stefanović ${ }^{2}$
}

Why were infants buried beneath house-floors at the Mesolithic and early Neolithic site of Lepenski Vir? Undertaking a new analysis of the neonate remains at Vlasac and Lepenski Vir the authors reject the idea of sacrificial infanticide, and demonstrate a consistency of respect in these burials. They suggest that the deaths were mourned and the dead, like the living, were given protection by the houses they were buried in. The treatment of mothers and children suggests increasing social cohesion from the Mesolithic at Vlasac to the early Neolithic at Lepenski Vir.

Keywords: Mesolithic, Neolithic, Danube Gorges, Lepenski Vir, infant burial

\section{Introduction}

Vlasac and Lepenski Vir are key sites for the Mesolithic-Neolithic transition in south-east Europe that feature rich burials, including many infants and subadults. Both sites provide the possibility of examining social attitudes to the death of the young and shed light on the importance of these age groups for the reproduction of social units over time. In spite of several analyses of human osteological material from the area of the Danube Gorges, there has been little integration of the results from physical anthropology and the archaeological context of the burials. In a programmatic step to overcome this research bias, we initiated a re-analyses of infant burials from Vlasac and Lepenski, focussing on this group because of a large number of infant burials and their striking spatial patterning. Mortuary data from Vlasac and Lepenski Vir provide the possibility of defining transformations in cultural attitudes towards infant deaths.

\section{The archaeology of the Danube Gorges}

The archaeological sites in the Danube Gorges were excavated through rescue projects in the 1960s-1970s on both the Serbian and the Romanian sides of the Danube (see Figure 1). Sequences at sites such as Lepenski Vir, Vlasac, Padina and Schela Cladovei document the transformation of fisher-hunter-gatherers of the Mesolithic period (c. 10 000-6300 CalBC) to early pottery users of the Early Neolithic (c. 6300-5500 CalBC) (e.g. Srejović 1969, 1972; Chapman 1992; Radovanović 1996; Bonsall et al. 2000; Borić 1999, 2002a, 2002b;

1 Center for Archaeology, Columbia University, 961 Schermerhorn Extension 1190 Amsterdam Avenue, MC 5538, New York, NY 10027, USA. (Email:db2128@columbia.edu)

2 Department of Archaeology, Faculty of Philosophy, University of Belgrade, Cika Ljubina 18-20, 11000 Belgrade, Serbia and Montenegro. (Email: smstefan@f.bg.ac.yu) 
Tringham 2000). Sites in the Upper Gorge (Vlasac, Lepenski Vir and Padina) contained remains of trapezoidal floors with rectangular stone hearths, sculptured boulders and complex sequences of human burials. Subsistence focused on both the river and the hinterland areas, and faunal remains included red deer, pig, aurochs and abundant fish bones. The most problematic issue at Lepenski Vir is the presence of Early Neolithic pottery in the trapezoidal buildings, and their absolute dating (cf. Borić 1999, 2002a; Garašanina \& Radovanović 2001; Tringham 2000).

Isotopic measurements of stable carbon and nitrogen suggest a possible dietary

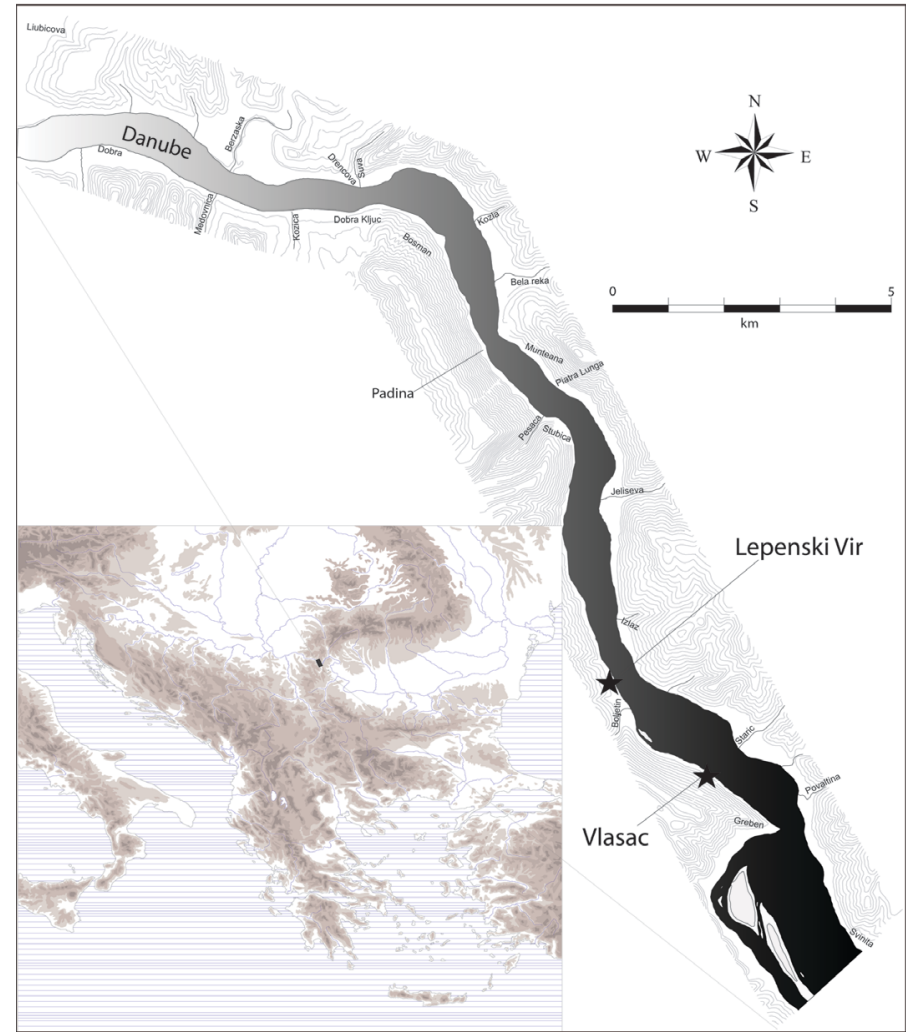

Figure 1. Map showing the Upper Gorge sites with Mesolithic-Early Neolithic sequences in the Danube Gorges.

shift in the Neolithic, i.e. after c. 6100 CalBC (cf. Bonsall et al. 2000; see also Grupe et al. 2003 and Borić et al. in press). Although isotopic measurements were analysed for ten children from Lepenski Vir and 7 from Vlasac by Bonsall et al. (2000: 125-6) it is not possible to relate palaeodietary results to particular individuals as information on what skeletons were analysed was not published in their report. (For new stable isotope analyses of this material see Grupe et al. 2003 and Borić et al. in press).

There are more than 500 burials in the Mesolithic and Early Neolithic sites on both sides of the Danube in this region (Roksandić 1999, 2000; Radovanović 1996; Boroneant et al. 1999; Boroneant 2001), and the buried individuals represent only a selected portion of the population that inhabited the region over several millennia. A variety of burial positions is recorded: extended inhumations, burials in a sitting position with crossed legs, crouched/flexed burials, group burials, cremations and partial burials with disarticulated cranial and postcranial bones. There is a pronounced manipulation and circulation of detached skulls and mandibles. A relatively large number of infant and subadult individuals are attested at Vlasac and Lepenski Vir. The category 'infant' here designates individuals up to one-year old. A large majority of Vlasac and Lepenski Vir infant burials are neonates. There are two foetuses at Vlasac and there are several possibly older infants at both Vlasac and Lepenski Vir on the basis of size of long bones. Ageing infant burials on the basis of size of long bones must be considered only as an approximate estimate ( \pm several weeks). Here, we describe infant burials from these two sites. 


\section{Birth and death}

\section{Vlasac}

Some $640 \mathrm{~m}^{2}$ were excavated at Vlasac in 1970-1971 (Srejović \& Letica 1978). The site is largely dated to the Mesolithic phase, with some possible Early Neolithic features and burials. The excavators reported three stratigraphic phases (Vlasac I-III). Burials are found around rectangular hearths and structures with the trapezoidal base (Figure 2). AMS dates on some of the human burials suggest an occupation at this site as early as c. $9800 \mathrm{CalBC}$, which might have lasted continuously at least up to c. 6900 CalBC (Bonsall et al. 2000: Table 3).

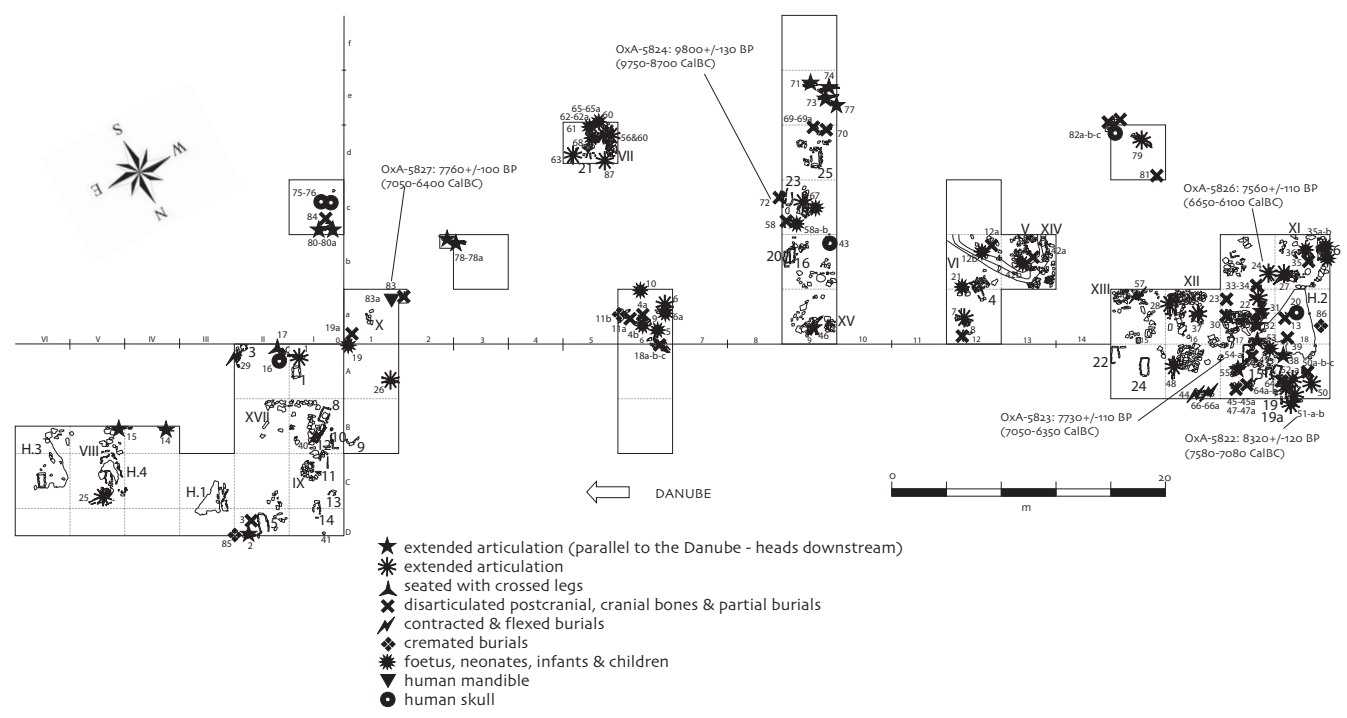

Figure 2. Vlasac - architectural features and burials from all phases (modified after Srejović \& Letica 1978). AMS dates on human burials corrected for the fresh water reservoir effect acc. to Method 2 as described by Cook et al. 2002.

Two physical anthropologists studied the human remains from Vlasac (Nemeskéri 1978; Roksandić 1999, 2000). There are 87 graves at the site. The sex and age structure shown in Figure 3 is based on the most recent re-analyses of the human bones (Roksandić 1999, 2000).

On the basis of our reanalyses of infant burials, there are 26 foetal and neonate burials at Vlasac (see

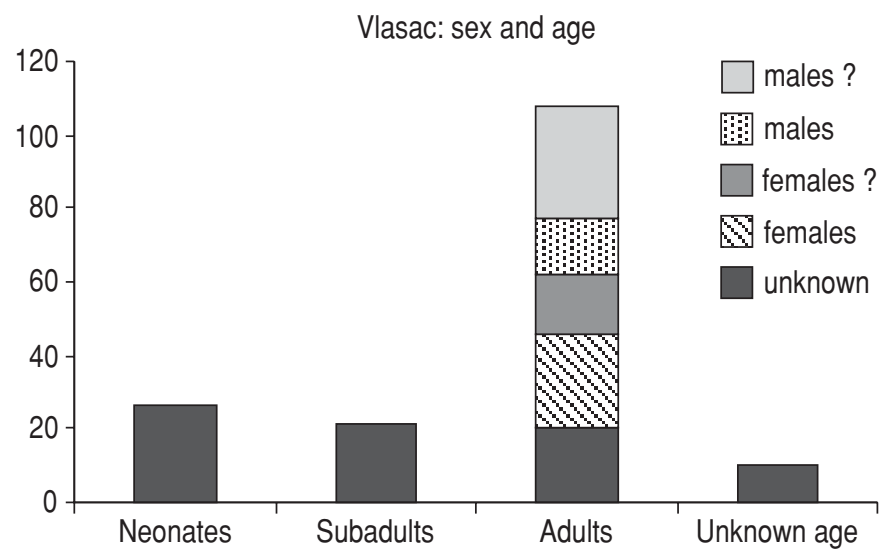

Figure 3. Age and sex structure of the human remains from Vlasac $(N=165)$ (after Roksandić 1999, 2000).

Table 1) and their age structure is shown in Figure 4. The estimated gestational age is based on the maximum length of femur and/or humerus (Bass 1987; Mays 1999), but in four 


\section{Dusan Borić \& Sofija Stefanović}

instances we estimated the age also on the basis of tibia and radius lengths. According to their burial context, foetal and neonate burials at Vlasac can be separated into four groups: a) found in the pelvic area of a pregnant woman (Burial 67), b) found with adult individuals during anthropological analyses, some possibly pregnant women (Burials 50[1], 50a[1], 55[2], 4b[1], 36[1],
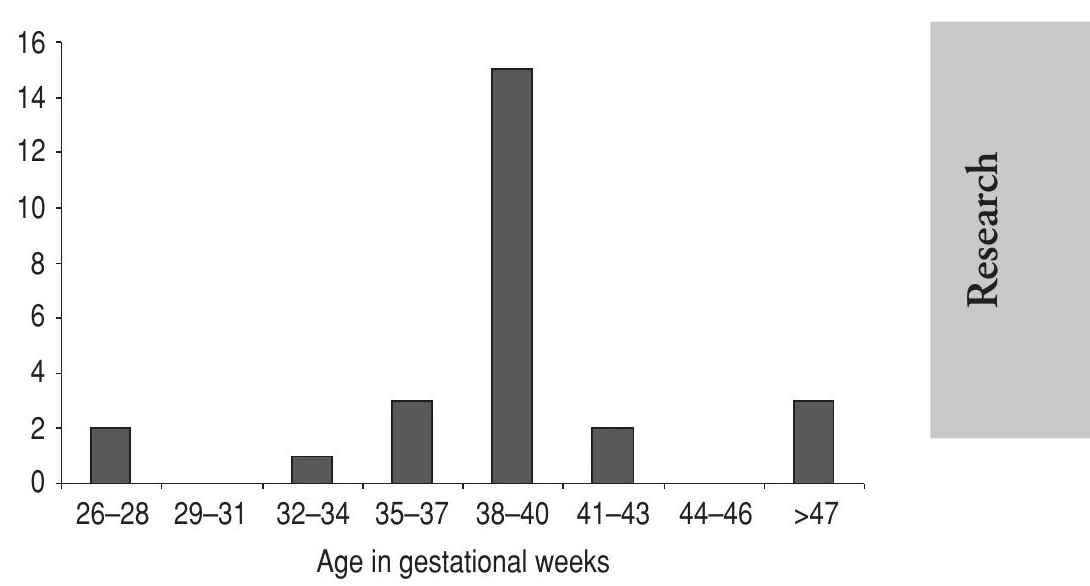

49[2], 60[1], 84[1]), c) clearly buried with an adult individual after the birth (Burials 58b by the legs of Burial 58 and Burial 6 a on the right chest of Burial 6) and d) found as separate burials (Burials 10, 12, 12b, 19, 21, 21[1], 35a, 36[1], 42a, 42b, 59, 61, 62, 66b). Note that in previous anthropological analyses, adult Burials 6 (Figure 5), 50, 50a, 58, 60, 84, which have associated remains of neonates, were sexed as male individuals (Nemeskéri 1978). The main criteria used to attribute sex to these individuals were robust features of their skulls. In the most recent re-analyses with more restrictive criteria used in the attribution of sex, Burials 6, 50a, and 84 were sexed as "males?" (see Figure 3) only on the robusticity criteria while Burial 60 was sexed as clearly male and 50 was left unsexed (Roksandić 1999: appendix 1).

In Burial 67, foetal bones were found in the pelvic area and mother and child most likely died prior to the birth. Other individuals are much closer to the expected time of birth, i.e. aged at around 38-40 gestational weeks. It is possible that some of the individuals found with adults died together with their mothers immediately prior to birth or during birth. Two individuals of neonate age, Burials 58b and 6a, clearly died after birth and were buried together with adult individuals who could have been their mothers or, if males, acting as protective maternal figures (see Figure 5). There are a number of infant burials that were buried separately. These include both neonates and infants between 2 and 4 months old. This older age is partly reflected in the special body treatment and offerings. For instance, Burial 21 was placed next to Hearth 4 (see Figure 2) with 50 perforated shells of Cyclope neritea Linnaeus snails and covered by Cyprinidae teeth (Srejovic \& Letica 1978: 58), while Burial 42 was found beheaded and covered by Cyprinidae teeth and red ochre (ibid.: 58).

The body treatment of adult burials with neonates is telling - Burial 67 with foetal bones was covered with red ochre over the groin area and the deceased's right hand was placed on the lower belly (ibid.: 57) while on the bones of Burial 6, with neonate Burial 6a on its chest (Figure 5), red ochre was found on the ribs and vertebrae, i.e. where the child was placed (ibid.: 68). Red ochre was noted on adult Burial 50 (ibid.: 59) and red ochre and Cyprinidae teeth were found covering adult Burials 49 and 50a. In a particularly interesting context, adult Burial 60 was found with neonate bones (Burial 60[1]) and was covered by Cyprinidae teeth over the groin area, while neonate Burials 59, 61 and 62 were found in small oval pits 


\section{Birth and death}

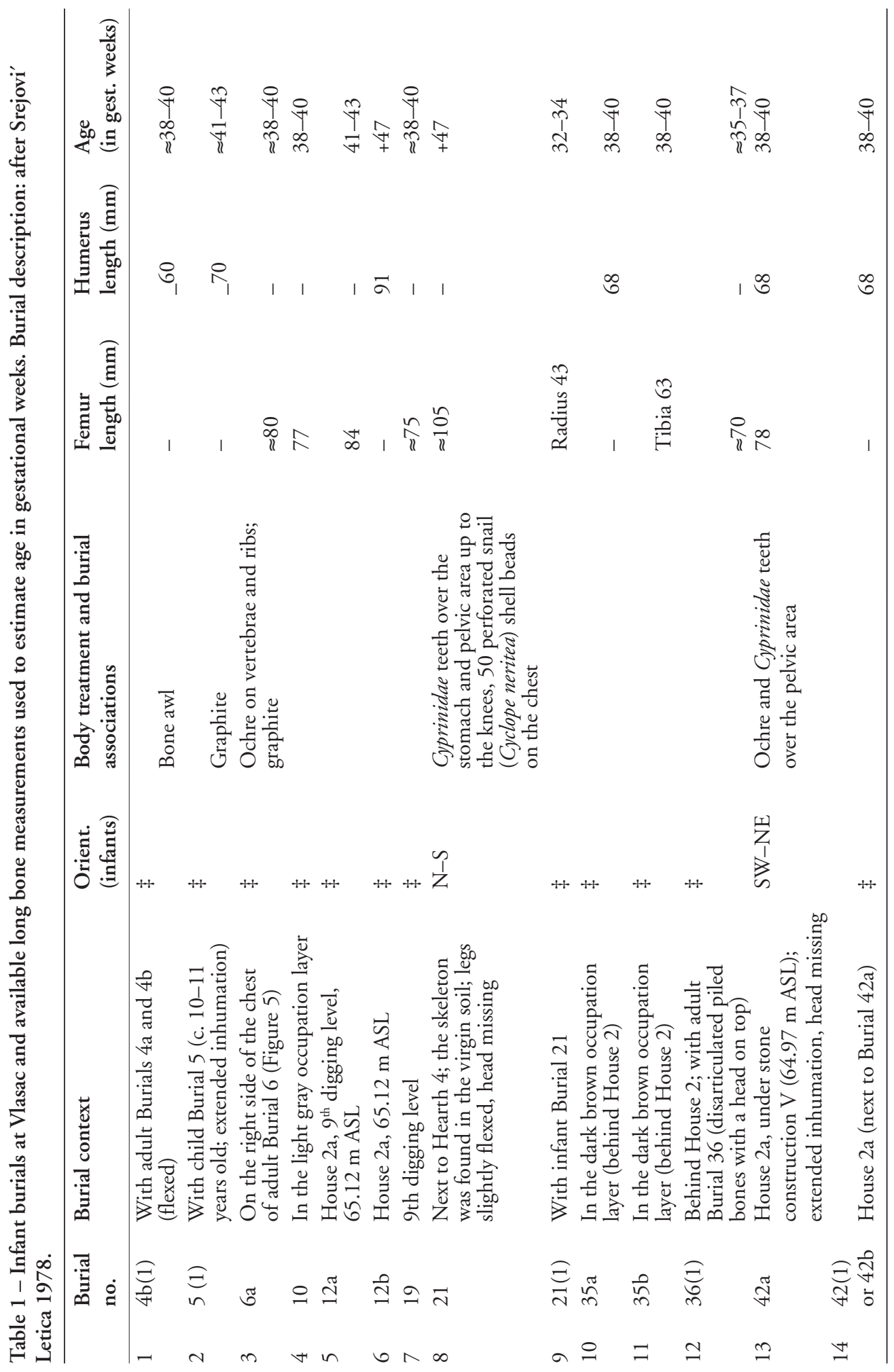


Dusan Borić \& Sofija Stefanović

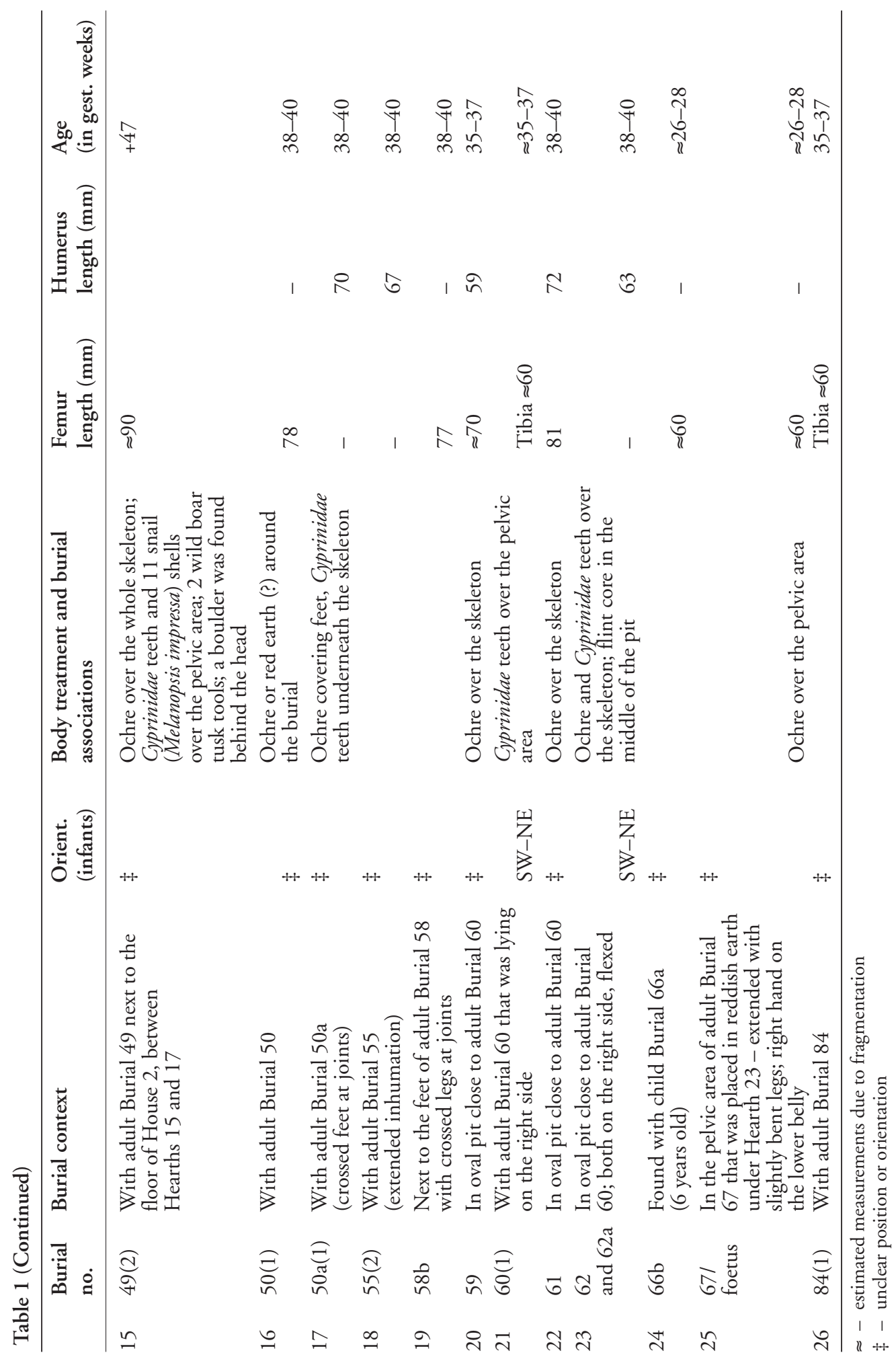


next to Burial 60 completely covered with red ochre (ibid.: 60) (Figure 6).

\section{Lepenski Vir}

Lepenski Vir is the type-site for the entire Iron Gates/ Danube Gorges regional group. The preserved area of the settlement (c. $2400 \mathrm{~m}^{2}$ ) was completely excavated between 1965 and 1970 (Srejović 1969a, 1972, 1981). There are at least 73 structures, termed 'houses' or 'shrines' with trapezoidal floors plastered with red limestone (Figure 7). Rectangular hearths made of vertical stone slabs were placed in the centre of each dwelling and sculptured boulders with fish-human features were found on building floors, primarily around the hearth area. The excavator reported four major phases with several sub-phases (Proto-Lepenski Vir, Lepenski Vir Ia-e, Lepenski Vir II and Lepenski Vir IIIa-b). However,

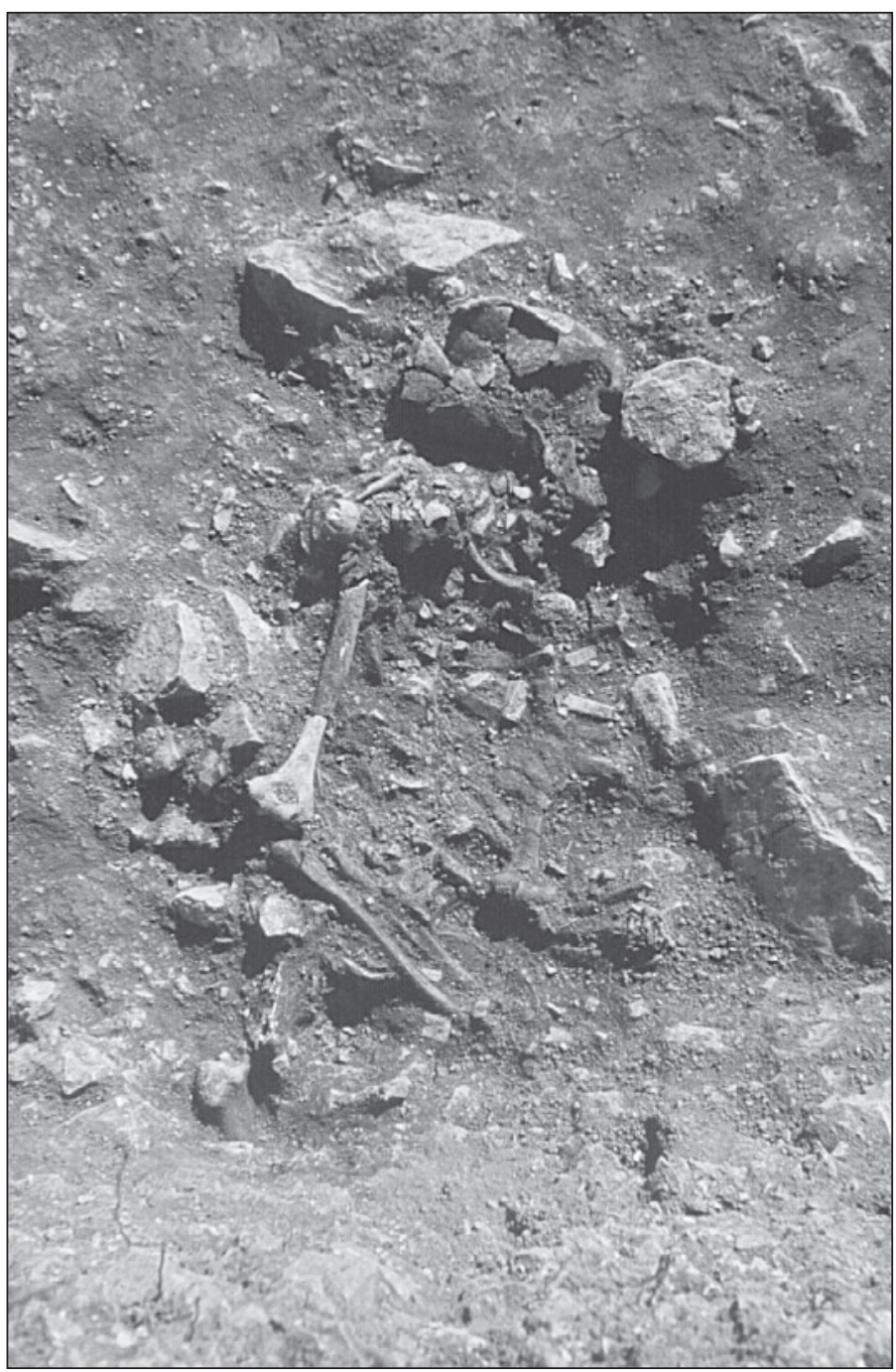

Figure 5. Neonate Burial Ga found on the chest of Burial 6 at Vlasac (photo: Centre for Archaeological Research, Belgrade).

radiometric dates from this site and material culture associations realistically indicate two distinct periods in the occupation at the site - Proto-Lepenski Vir, representing a Mesolithic phase around $7500 \mathrm{Cal} \mathrm{BC}$ and Lepenski Vir I represented by the trapezoidal buildings of Early Neolithic age, c. 6300-5500 CalBC (Borić 2002a, Whittle et al. 2002) - while there remains a possibility for a continuous sequence between the two periods.

Nemeskéri (1972), Zoffmann (1983) and Roksandić $(1999,2000)$ have studied the human remains from this site arriving at different sex and age estimates. The 134 reported graves contained the remains of c. 190 individuals. The sex and age structure shown in Figure 8 is based on the most recent re-analyses of human bones.

On the basis of our re-analyses, there are 41 neonate burials at Lepenski Vir (Table 2) and their age structure is shown in Figure 9. The estimated gestational age is based on the maximum length of femur and/or humerus (Bass 1987; Mays 1999). Neonate burials from Lepenski 
Vir were found underneath floors of trapezoidal buildings (cf. Radovanović 1996; Srejović 1969a, 1981; Stefanović \& Borić in press). These burials are stratigraphically connected with 19 trapezoidal structures and were placed exclusively in the rear of the buildings (Figures 10 and 11). The burial pits either cut the limestone floors or were dug immediately off the floor edge, frequently between the construction stones surrounding the floor. In one

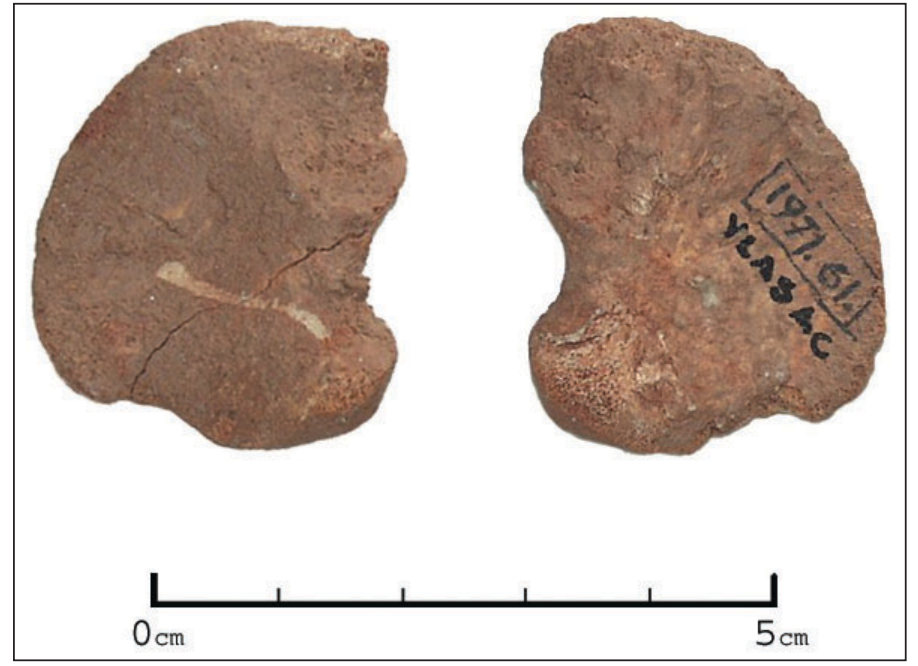

Figure 6. Bones of neonate Burial 61 buried in an oval pit covered with red ochre at Vlasac.

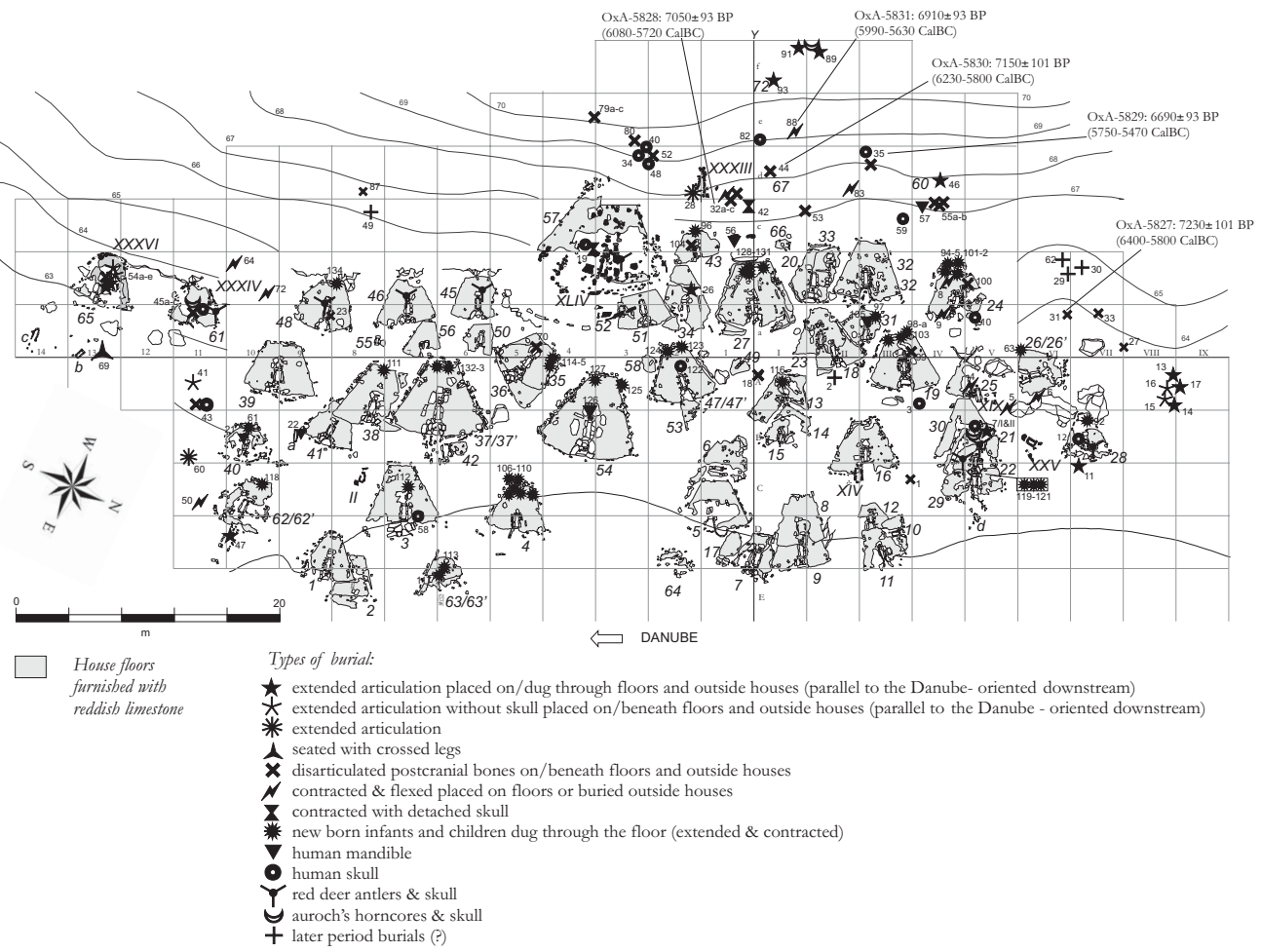

Figure 7. Trapezoidal buildings and construction stones of Lepenski Vir I phase according to Srejović (after Srejović 1981: 2021) and types of burial on/beneath building floors and outside buildings from all phases. Large arabic numbers indicate buildings of Lepenski Vir I, small arabic numbers burials (all phases). Some features of Lepenski Vir II are also shown here and are marked by roman numbers. AMS dates on human burials corrected for the fresh water reservoir effect acc. to Method 2 as described by Cook et al. 2002. 


\section{Birth and death}

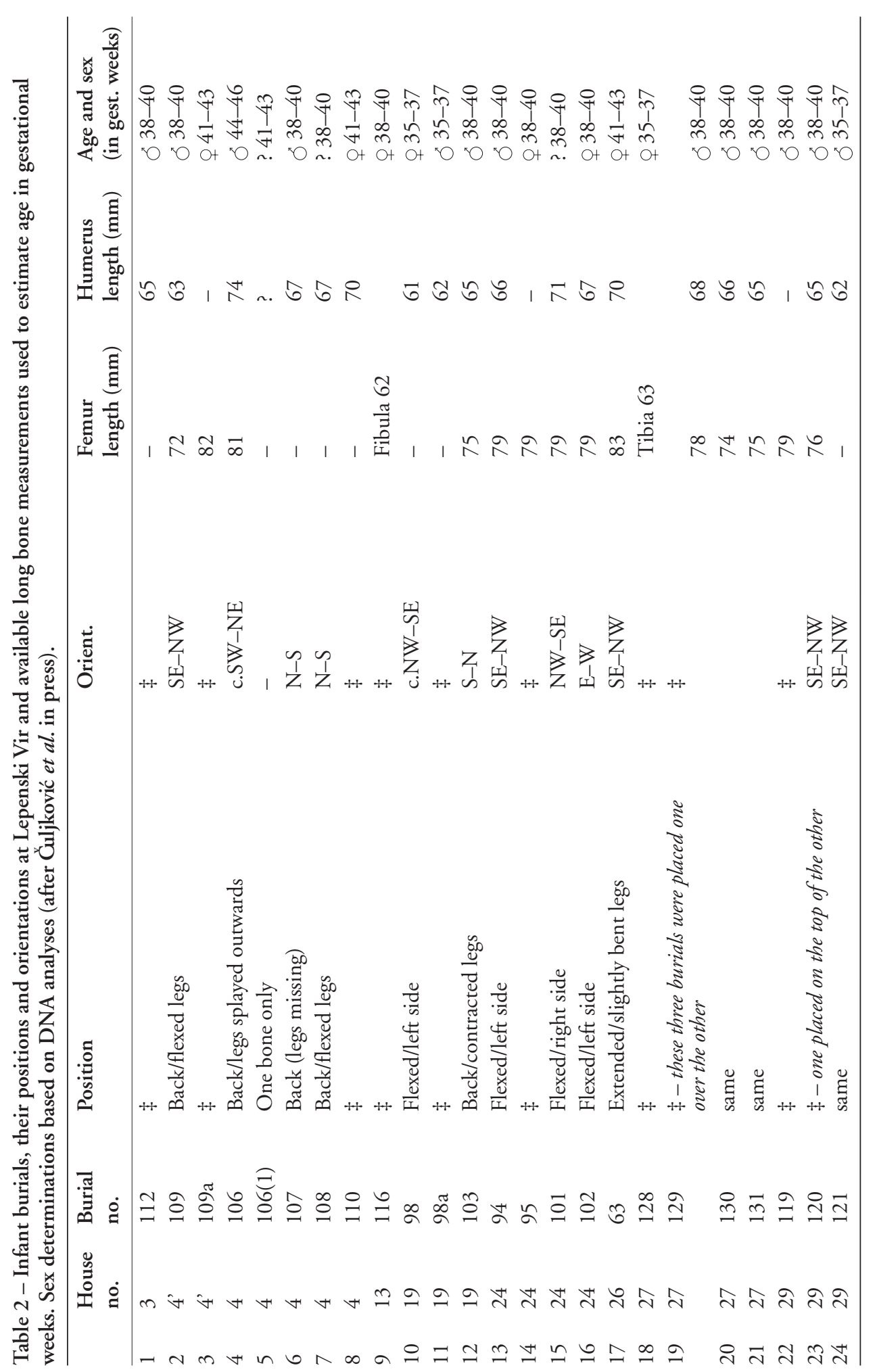


Dusan Borić \& Sofija Stefanovic

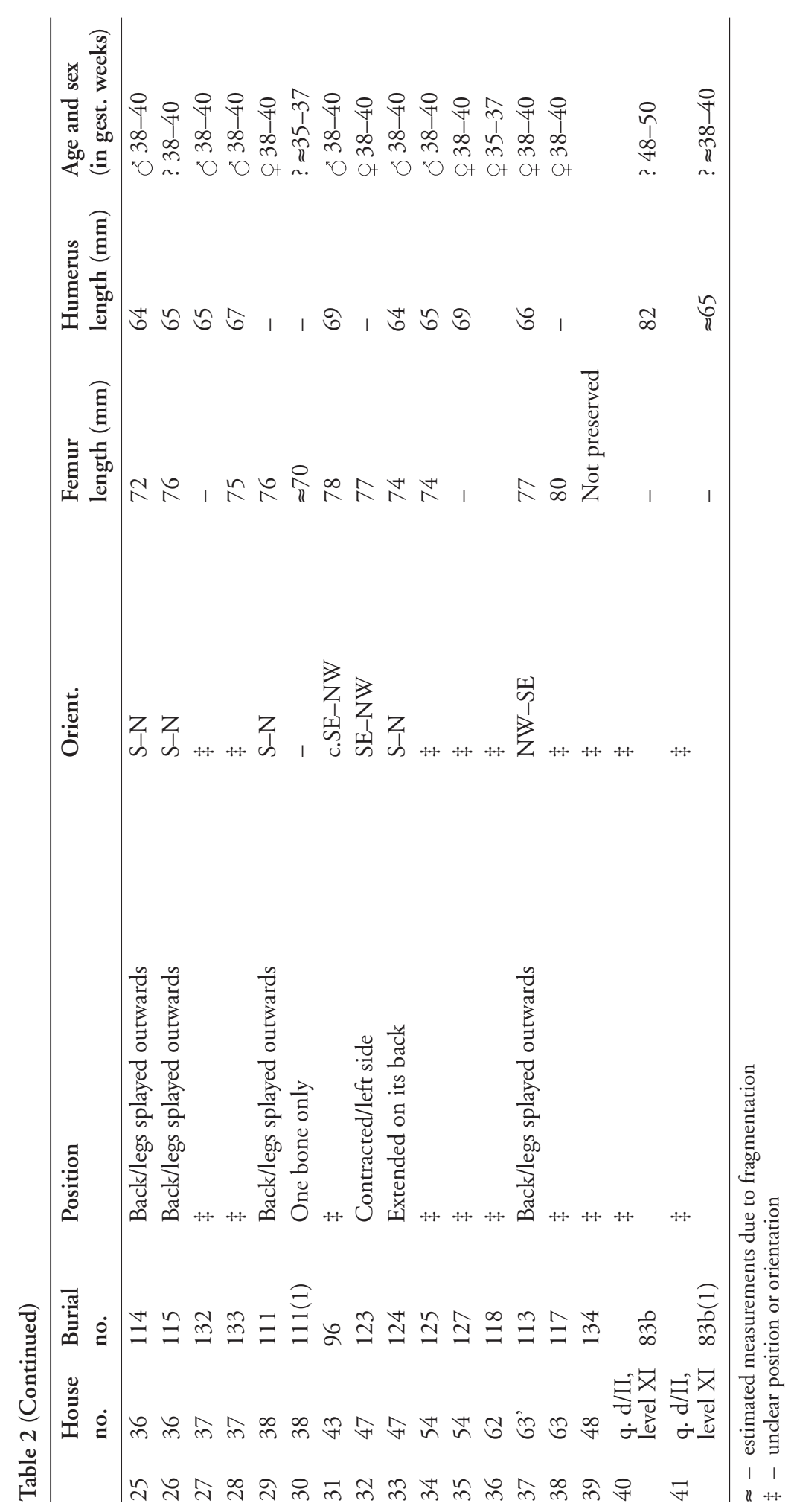


case neonate Burial 63 was found at the front corner of House 26 (Borić 1999: Figure 19). This exception is due to the unusual orientation of this building - parallel to the Danube along its longer axis (see Figure 7). The clearest example of burials being cut through the limestone floor and not interred before plastering the floor (contra Srejović 1969: 136; 1972: 119; contra Radovanović 2000, 340, n. 7) is Burial 113

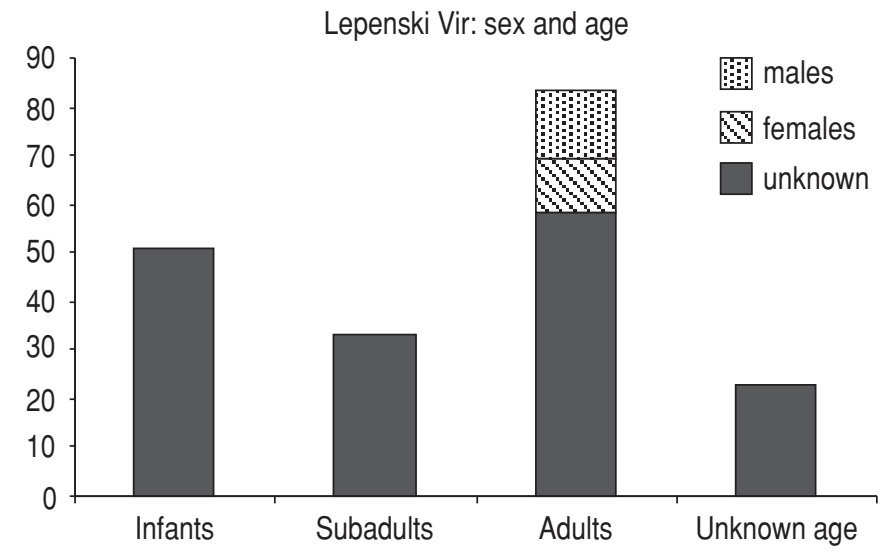

Figure 8. Age and sex structure of the human remains at Lepenski Vir $(N=190)$ (after Roksandić 1999, 2000).

in House 63' - a burial pit cut through the floor is clearly visible with a stone block placed over it (Figure 11). In a number of instances, burial pits of oval and rectangular shape were visible in the virgin soil only after the floor was removed (Burials 94, 103,106, 107, 128-131 and 132) (e.g. Figure 12). This is due to the very small diameter of these pits and, frequently, extensive damage of the limestone floor. A number of neonate burials were oriented with the heads toward the south-east or the south, i.e. approximately parallel to the Danube with their heads pointing downstream. This position/

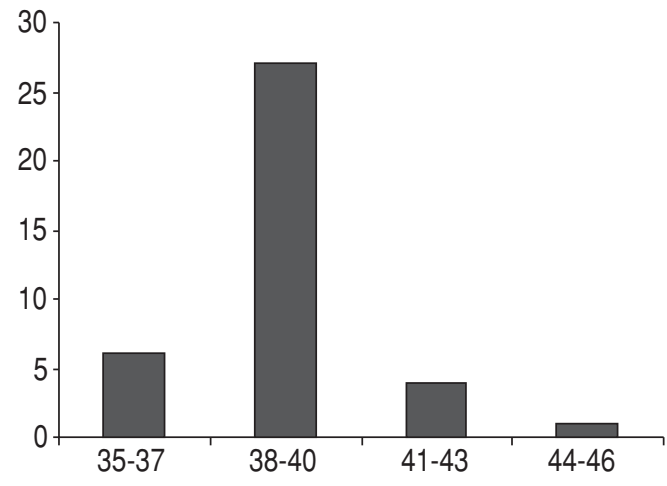

Figure 9. Neonates at Lepenski Vir (without Burials 134, 836 and $836[1])$ with estimated age in gestational weeks $(N=38)$.

orientation is similar to some adult burials from Lepenski Vir and other sites in the Danube Gorges and might have been imbued with some ideological and/or religious significance (cf. Radovanović 1997). Still, within the same building, neonate burials were also found oriented with their heads pointing to the north-west, north or north-east (see Table 2). In some cases, stones bordered particular burials (Burials 63, 106, 125). There were few exceptions to the context of burial beneath the floor: Burials $83 \mathrm{~b}$ and $83 \mathrm{~b}(1)$ were not associated with architectural features and are possibly of a different chronological age. The remains of infant Burial 134 found in the rear of House 48 were not preserved after the excavation (Lepenski Vir Field Diary, 1970).

No grave offerings were found in neonate burials at this site. Only in the infill of Burial 113 (House 63') were two small fragments of Early Neolithic pottery found (Lepenski Vir Field Diary 1970). It is unlikely that these fragments represent intentional deposition but were rather residually present in the burial infill (for discussions about the presence of pottery in trapezoidal buildings see Borić 1999, 2002a; Garašanina \& Radovanović 2001). 
Dusan Borić \& Sofija Stefanović

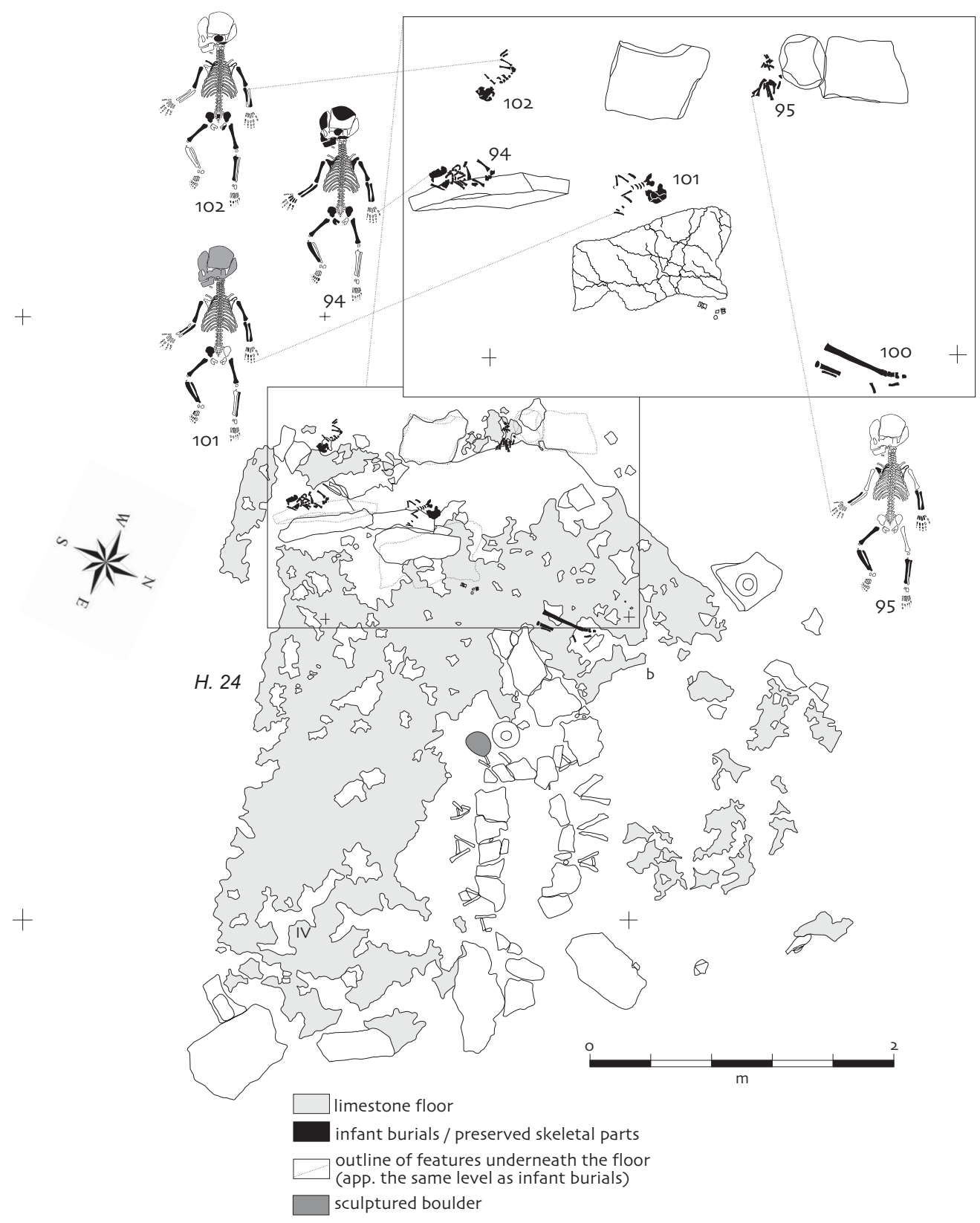

Figure 10. House 24 and neonate Burials 94, 95, 101 and 102 at Lepenski Vir. 


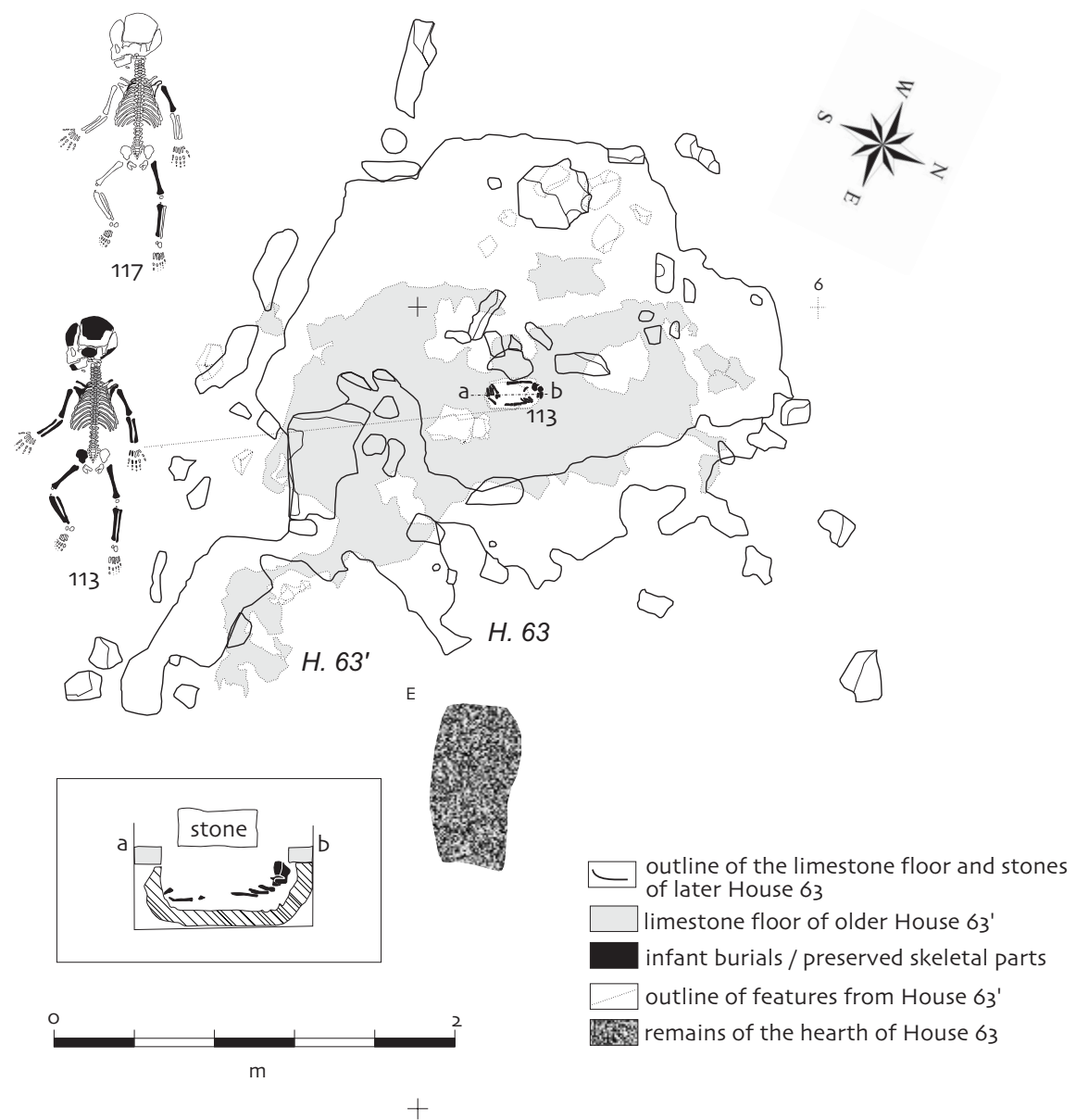

Figure 11. House 63' and a cross-section of the burial pit for neonate Burial 113 covered by a stone block at Lepenski Vir.

In a number of instances, it was not possible to establish the exact position of the skeleton (see Table 2). Although the taphonomic condition of neonate burials on the whole is good at Lepenski Vir, later disturbances might have been responsible for these unclear positions. For instance, placing a new interment in the same area could have disturbed earlier skeletons, affecting their preservation (e.g. Burial 98a disturbed by Burial 98 in House 19, Burial 110 disturbed by Burial 107 in House 4 and Burial 109a disturbed by Burial 109 in House 4'). It is possible that interment of Burials 129, 130 and 131 (House 27) and Burials 120 and 121 (House 29) took place at the same time in the respective buildings (see Stefanović \& Borić in press). Recorded burial positions include: a) extended, b) contracted/flexed and c) a position with legs splayed outwards (see Table 2). In some burials only legs were contracted while the torso was lying on the back. The third group in the position with legs splayed outwards (with the heels below the pelvis and noted in the 1970 Field Diary as 'sitting') is especially interesting. It is possible to explain this position by reference to the process of re-enacting, i.e. re-fleshing 
the body (cf. Hawkes with Molleson 2000), thus discerning a specific body treatment prior to the burial. This specific burial position could be a consequence of placing neonates in a bag prior to their interment in a small burial pit. In the process of decay the bones of the skeleton would slump depending on how the bag containing the neonate's body was placed in the ground. If neonate's body was put contracted in a bag and placed on its back, the legs would slump either outwards to the sides, or both legs would slump to one side. In addition to neonate burials found in this position, child Burial 97 (around 2-6 years old) in House 31 was found in a similar position too (Figure 13). It is worth noting that possibly chronologically older houses contained burials in this position. On the other hand, both contracted (Burial 123) and extended (Burial 124) burials were noted in House 47 and it is unclear whether these after positions can chronologically be differentiated (see Stefanović $\&$ Borić in press).

Similar to the pattern of neonate interments in the rear of 19 buildings, another older child Burial 92 (around 2 years old) was found in the rear of House 28, under a large stone block flanked by two stone sculptures (Stefanović \& Borić in press; cf. Srejović 1972: Figure $10,14)$. We shall contextualise this instance in the following discussion.

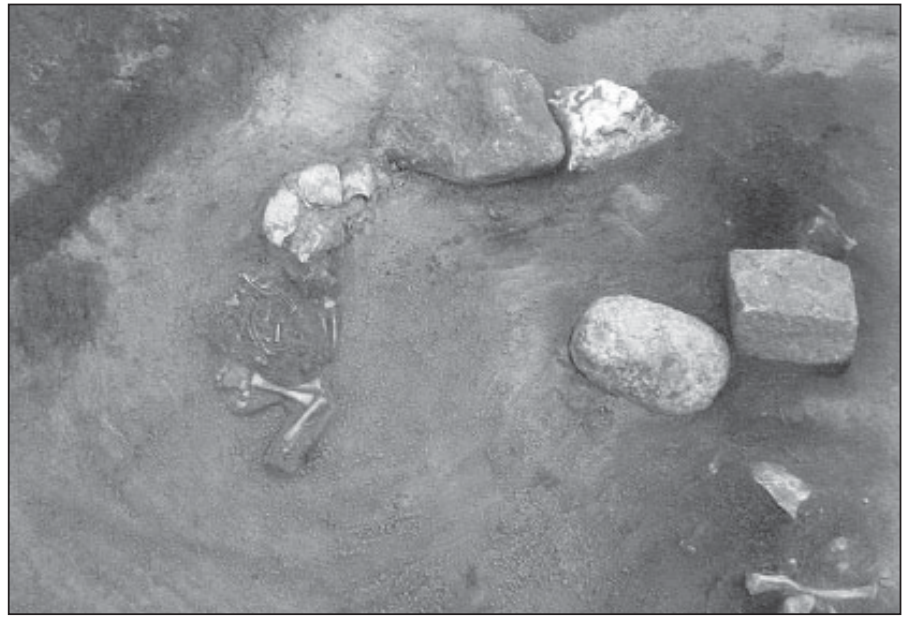

Figure 12. Neonate Burial 98 after lifting the floor of House 19, Lepenski Vir (photo: Centre for Archaeological Research, Belgrade).

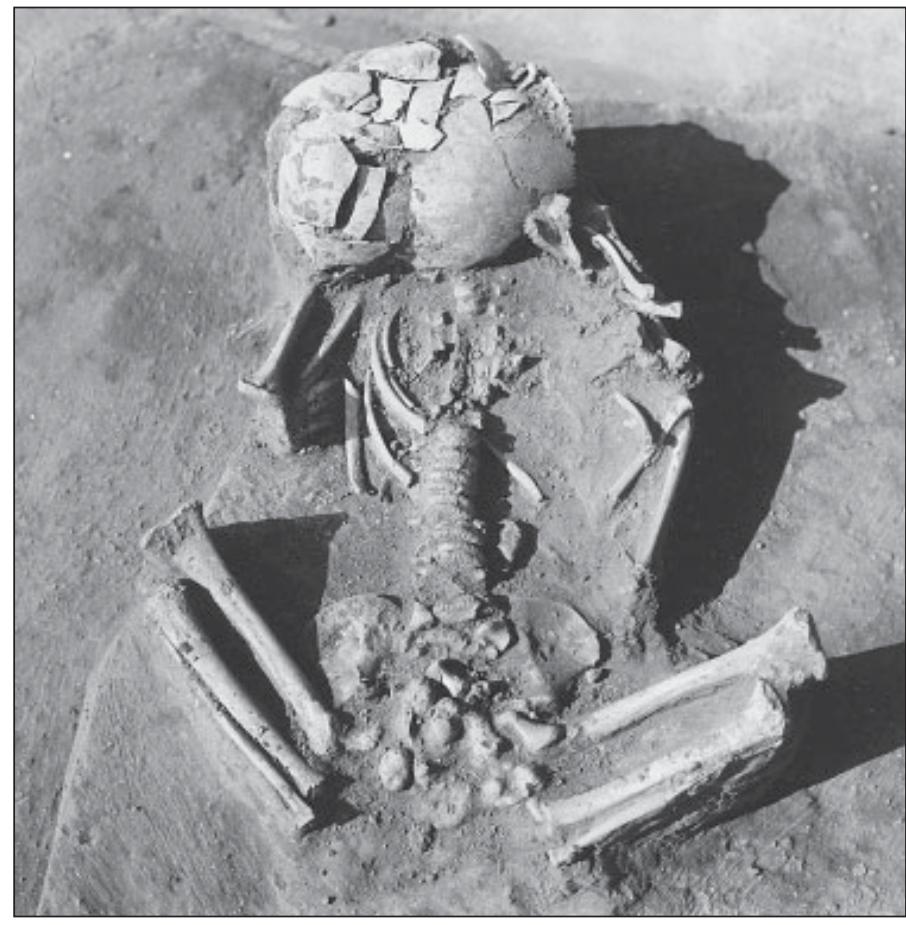

Figure 13. Child Burial 97 underneath the floor of House 31, Lepenski Vir (photo: Centre for Archaeological Research, Belgrade). 


\section{Birth and death}

\section{Discussion and interpretation}

Taphonomically, neonate burials from Lepenski Vir are better preserved than those from Vlasac. This differential preservation is due to a different deposition and archaeological context at the two sites. We noted some signs of classically described nutritional deficiency at Lepenski Vir, such as cribra orbitalia on Burial 120 (House 29). Burials 106 and 107 in House 4 had irregular growth of claviculae. Irregular growth of long bones and porosity were noted on Burials 108 in House 4, 109 and 109a in House 4', 114 in House 36 and 121 in House 29. There are 19 male and 14 female neonates from Lepenski Vir on the basis of the DNA analyses (Table 2; Culjković et al. in press) and hence no clear preference for only one sex. The DNA analyses further suggest a heterogeneous structure of the population among the houses on the basis of this material (ibid.).

There is a clear difference between Vlasac and Lepenski Vir in the burial treatment of infants. At Vlasac, the prevalence of neonate burials with mothers (but also with, in one instance, at least one male adult too) indicates a pronounced concern for the death of pregnant women, some of who might have died giving birth or during pregnancy. In several cases it seems that both mother and a child died immediately after the birth and were buried together (e.g. Burials 6-6a, Figure 5). The pronounced concern for both the mother and child is emotionally moving in the instance where the hand of individual in Burial 67 was placed over the lower belly with the unborn baby. It seems that the practice of covering the pelvic area or the whole body with red ochre relates to mothers and infants in particular. Similarly, after re-examining Cyprinidae teeth found in burials, one of us (DB) noted that a number of these had small perforations on the root and might have been attached as part of a garment (possibly to some kind of apron or string skirt) (Borić 2002b). These again could specifically relate to women and infants. Infant Burial 21 (2-4 months old) was buried separately with 50 perforated snails and this probably reflects its stage of social embodiment, which sharply differs from neonates.

A different treatment of Lepenski Vir neonates can be explained as a consequence of culture changes affecting the community in the Gorges in a diachronic perspective. One of the main differences at Lepenski Vir is that neonates are no longer buried with adults in the space around open-air hearths and stone constructions but as separate burials under red limestone floors of trapezoidal buildings, always in the rear of a building. This change in the burial rite possibly suggests some major social and ideological restructuring in the Danube Gorges, or at least in the Upper Gorge, at the beginning of the Early Neolithic, i.e. c. 6300 CalBC, at the time when, also, the first elaborate trapezoidal buildings appear at Lepenski Vir. There are no ${ }^{14} \mathrm{C}$ dates for neonate burials and we date them stratigraphically, i.e. in relation to the dating of a particular building.

The association of infant and subadult burials with architectural/dwelling structures is recurrent throughout the Neolithic Balkans and eastern Mediterranean (e.g. Whittle et al. 2002; Zoffmann 1988; Brukner 1960; Benac 1973; Gimbutas [ed.] 1976; Demoule \& Lichardus-Itten 1994; Rodden 1965; Gallis 1996; Jacobsen 1976; le Brun 1989, 1997; Mellaart 1967; Hodder 1999; Molleson et al. http://www.catalhoyuk.com/). With regard to the frequently debated issue as to whether we are dealing with the practice of infanticide when encountering a large number of infant burials in an archaeological record, we see no 
reason to interpret burials at Vlasac and Lepenski Vir as victims of infanticide, regardless of a high death peak between 38-40 gestational weeks (cf. Mays 1998: 66). This conclusion is based on the following:

- there is a considerable communal concern expressed towards infants and pregnant women at chronologically earlier Vlasac, which can hardly speak in favour of an infanticide tradition in this cultural context

- neonate burials at Lepenski Vir were not buried before the floor of a building was furnished (contra the scenario regarding possible 'sacrificial deposits') but burial pits were cut through already existing floors

- infant and children burials were also found underneath floors of buildings in a number of pre-Neolithic and Neolithic contexts of the eastern Mediterranean, and the meanings surrounding these practices might have been shared.

Why were neonates especially selected for burial in this particular way under floors of the Lepenski Vir trapezoidal buildings? This question can perhaps be answered by looking at some other burials also found interred into cuts made through the floors of buildings of Lepenski Vir. Adult Male Burials 26 (House 34) and 7/I-a (House 21) and child Burials 61 (House 40) and 92 (House 28) were cut through the floors of their respective buildings (cf. Srejović 1969, 1972; Radovanović 1996; Stefanović \& Borić in press). These are all extended inhumations, lying parallel to the Danube, heads pointing downstream. Adult Male Burials 26 and 7/I-a were placed immediately behind the back area of the hearths while subadult Burials 61 and 92 were found placed more to the rear of their respective buildings, similar to the position of neonates. This spatial patterning reflects differences in rank and gender, possibly inscribed onto the division of building space (see Stefanović \& Borić in press).

A possible interpretation for burials cut through building floors can be related to ideas about 'houses' as places that embodied ancestral powers. Disarticulated cranial and postcranial bones were found on building floors at Lepenski Vir, and in the case of Burial 7/I-a a detached human skull with a pronouncedly robust features (perhaps considered as 'ancestral') was placed to accompany the burial (cf. Srejović 1972: Figure 61; Radovanović 1996: Figure 4.3), possibly acting as a heirloom or relic (Borić 2003). Sculptured boulders found in many buildings are also possibly sacred heirlooms that indicate ambiguous meanings of these spaces with both sacred and profane connotations. To bury neonates within the 'house' space might have been seen as both protective for their ungendered souls in the spirit world of the afterlife and important for the reproductive potency of the building seen as an embodiment of a lineage. One instance from Balkan ethnography may be particularly evocative in this context. Among the Saracatsans, pastoral nomads in the Balkans, in the case of the death of a newborn or a miscarriage there was a widespread custom up until 1940 to put the child in a bag full of salt and to hang it above the parents' marital bed for approximately forty days, until the child's corpse dries out. After this period the corpse of the deceased child in the bag is buried in a pit dug in a corner of the hut $\chi \alpha \alpha^{\prime} \tau \xi \eta \mu \chi \alpha \alpha \lambda \eta$ 1957: 68 cited by Antonijević 1982: 134).

Similar examples of the connection between new-borns and houses are found in other cultures (e.g. Bloch 1995; Rivière 1995; Gibson 1995; Gillespie 2000: 219, note 8; Waterson 1990, 2000), while some comparative studies of folk dress in the Balkans and Anatolia identify concerns that connect issues of the protection and fertility with mothers and children (cf. 
Welters 1999). In Tana Toraja, South Sulawesi, Indonesia, through successive generations, fathers would bury placentas (seen as a 'twin' to the baby) of new-born babies always at the same spot at the east side of a house that is associated with life and the rising sun (Waterson 1990: 198, 2000: 180, 182). In other Indonesian societies, such as the Timorese, the umbilicus and placenta would be placed in a bag and hung on the central (ancestral) pillar of the main room in a house. Similarly, in Tanimbar the placenta would be buried in the house floor (ibid.: 180). In another example from the same region, in the village of Ara, among the Makassarese of South Sulawesi, Indonesia, the birth is surrounded by extensive magic rituals intended to facilitate the delivery and protect the baby (but also the mother) from evil forces and spirits that can harm the baby while still "in the extremely vulnerable condition of having an unhealed navel and soft fontanelle" (Gibson 1995: 137).

Or one may evoke the notion of "boneless" baby that comes from the Vezo of Madagascar (Astuti 1998). The Vezo think that people are not born as humans, but become human as they get older. They see new-born babies as strongly tied with mothers, vulnerable and not fully human. Moreover, new-born babies are malleable and plastic, especially with regard to their facial features, and their bodies are soft and weak, i.e. 'boneless', and only have the potential to become "fully-boned" adults (ibid.: 36). Both mother and baby are vulnerable after the event of birth as their bodies can be penetrated by the deadly "air" and babies must be protected by being wrapped up in layers of clothes (ibid.: 35). Such small babies must not be left alone as they are unprotected from the harmful influence of abound kind of spirits angatse, which are the reason that eyelids of babies tremble and roll sideways every time the spirits are around. Another kind of danger comes from vengeful ancestors that can be badtempered and can easily harm a "boneless" baby. If a baby dies before it is one year old, it cannot be buried in a family ancestral tomb as it has not become a human, i.e. its social person has not been "created" yet (ibid.: 36-37). It is interesting to note that in the case of the Zafimaniry of Madagascar, houses, as people, also acquire 'bones' through their slow build up with more permanent material (from woven bamboo to massive wooden planks) and elaboration of specific decorative wood carvings, where the process of 'beautifying' the timbers makes a part in the process of the growth and successful marriage of the founding couple (Bloch 1995: 78ff).

In this context, could we maintain the idea that in our case study the described burial practices at Lepenski Vir are "the domestication of the death" by bringing the dead body into the house as suggested by Hodder (1990: 29)? Our analysis suggests that instead of the issue of control over the dead body, infant burials from Lepenski Vir may rather indicate an emotional response to the death of a new-born that is also constitutive of a concern and emphasis on the reproduction of more permanent social units embodied in trapezoidal buildings. These concerns might have also been expressed in one of the representational boulders found in House 57/XLIV, which is most likely a depiction of a hybrid fish/woman giving birth (Srejović \& Babović 1983: 114-115).

We suggest that the protective role of houses might have been seen as important for the dead as for the living at Lepenski Vir. The neonate, subadult and adult burials found placed in burial pits cut through building floors might have needed the protection of these structures, likely understood as lineage/ancestral focal points. The situation is different at Vlasac where infant burials are largely found in relation to an adult burial, and it could possibly indicate 
an expression of less nuclear social groupings during the Mesolithic period. The change seems to be related to new social and ideological frameworks that were promoted in the Early Neolithic context at Lepenski Vir. However, this apparent change in mortuary treatment of infants is rather an extension of the process that may already be observed at Vlasac where burials of various age groups were clustered around open-air rectangular hearths, possibly standing for a particular social group of a wider community.

On the other hand, the apotropaic character of infant burial practices might have been also directed towards the living community in order to appease possibly vengeful infant souls, trapped in the liminality of death experience for which they have not been prepared (cf. Bloch \& Parry 1982; Metcalf \& Huntington 1991; Bandić 1997). Hence, these practices might have been surrounded with possibly ambiguous but not contradictory concerns.

Certain elements related to the protective, i.e. apotropaic, principle of mortuary rites seem to remain the same in the diachronic perspective. Thus, it could be instructive to note that the colour of building floors at Lepenski Vir is red and that red ochre at Vlasac was extensively used in relation to deceased pregnant women (and some other adults) and infants; in both cases the colour red possibly marked a protective arena (Borić 2002).

\section{Conclusion}

The contextual study of neonate and infant burials from Vlasac and Lepenski Vir opens up a potential to discern specific stages of social embodiment related to age in these societies. It also provides the possibility of describing aspects of lived experience (cf. Meskell 1994, 1996) with a glimpse over the emotional side of disruptive life events, such as the death of newborns and pregnant women. On the basis of our findings, we are compelled to reject the infanticide/sacrificial deposit explanation for infant burials at the two sites, which is frequently related to a research practices of imposing savage stereotypes onto the past record (see Schrire $\&$ Steiger 1974). This conclusion is based both on the stratigraphic position of infant burials at Lepenski Vir that were interred into burial pits cut through the floor and not sacrificially deposited before the floor was furnished and, also, on the diachronically retained aspects of mortuary rites, which both at Vlasac and Lepenski Vir suggest a will to protect, directed both towards deceased infants and the living community.

Recently, there have been burgeoning fields of study, at least partly influenced by third wave feminism, that focus on varied aspects of childhood in the archaeological record (e.g. Sofaer Derevenski 1997; Scott 1999; Politis 1999; Joyce 2000). The previous discussion with regard to examples of Mesolithic and Early Neolithic infant burials from Vlasac and Lepenski Vir indicates that in both contexts a significant proportion of those selected for burials were infants and subadults. Moreover, it seems that the social and symbolic importance of new-born infants might have been equal to that of the 'big men' of the community concerning the reproduction of social units equated with particular houses.

\section{Acknowledgments}

We thank Professor Dr Živko Mikić (Faculty of Philosophy, University of Belgrade) for permission to work on infant burials from Vlasac and Lepenski Vir and Theya Molleson, John Robb, and Anna Boozer for valuable comments on earlier drafts of the paper. 


\section{Birth and death}

\section{References}

Antonijević, D. 1982. Obredi i obicaji balkanskih stocara. Beograd: Balkanološki institut.

Astuti, R. 1998. “It's a boy,” “it's a girl!" Reflections on sex and gender in Madagascar and beyond, in M. Lambek \& A. Strathern (eds.) Bodies and persons. Comparative perspectives from Africa and Melanesia: pp. 29-52. Cambridge: Cambridge University Press.

BANDIĆ, D. 1997. Carstvo zemaljsko i carstvo nebesko. Ogledi o narodnoj religiji. Beograd: Biblioteka XX vek.

BAss, W. 1987. Human osteology. New York: Missouri Archaeological Society.

Benac, A. 1973. Obre I. A Neolithic settlement of the Starcevo-Impresso and Kakanj culture at Raskrašće. Wissenschaftliche Mitteilungen des Bosnisch-Hercegowinisch Landesmuseums IIIA: 327430.

BLOCH, M. 1995. The resurrection of the house amongst the Zafimaniry of Madagascar, in J. Carsten \& S. Hugh-Jones (eds.): pp. 69-83. Cambridge: Cambridge University Press.

Bloch, M. \& J. Parry, 1982. Death and the Regeneration of Life. Cambridge: Cambridge University Press.

Bonsall, C., G. Cook, R. Lennon, D. Harkness, M. Scott, L. Bartosiewicz, \& K. McSweeney. 2000. Stable isotopes, Radiocarbon and the Mesolithic-Neolithic Transition in the Iron Gates. Documenta Praehistorica 27: 119-32.

Bonsall, C., V. Boroneant, \& I. Radovanović (eds) in press. The Iron Gates Prehistory: New Perspectives. Oxford: BAR.Int.Ser.

Boroneant, V. 2001. Palaeolithique superieur et Épipaléolithique dans la zone des Portes de Fer. Bucuretci: Silex.

Boroneant, V., C. Bonsall, K. McSweeney, R. Payton \& M. Macklin, 1999. A Mesolithic Burial Area at Schela Cladovei, Romania, in A. Thévenin (ed.), L'Europe des derniers chasseurs, Épipaléolithique et Mésolithique: pp. 385-90. Paris: Editions du CTHS.

Borić, D. 1999. Places that created time in the Danube Gorges and beyond, c. 9000-5500 BC. Documenta Praehistorica 26: 41-70.

-2002. Apotropaism and the temporality of colours: colourful Mesolithic-Neolithic seasons in the Danube Gorges, in A. Jones \& G. MacGregor (eds.), Colouring the Past. The Significance of Colour in Archaeological Research: pp. 23-43. Oxford: Berg.

-2002a. The Lepenski Vir conundrum: reinterpretation of the Mesolithic and Neolithic sequences in the Danube Gorges. Antiquity 76: 1026-1039. -2002b. Seasons, Life Cycles and Memory in the Danube Gorges, c. 10000-5500 BC Cal. Unpublished Ph.D. Dissertation, University of Cambridge, Cambridge.

-2003. 'Deep time' metaphor: mnemonic and apotropaic practices at Lepenski Vir. Journal of Social Archaeology 3(1): 46-74.

Borić, D., G. Grupe, J. Peters, \& Z. Mikić. in press. Is Mesolithic-Neolithic subsistence dichotomy real? Isotopic evidence from the Danube Gorges. Archaeometry.

BRUKNER, B. 1960. Rezultati zaštitnog iskopavanja lokaliteta "Baštine" kod sela Obreža. Rad vojvodjanskih muzeja 9: 81-111.

Le Brun, A. 1989. Fouilles Récent à Khirokitia (Chypre) 1983-1986. Paris: Éditions Recherche sur les Civilisations.

-1997. Khirokitia. A Neolithic Site. Nicosia: Bank of Cyprus Cultural Foundation.

Carsten, J. \& S. Hugh-Jones, (eds.) 1995. About the House, Lévi-Strauss and Beyond. Cambridge: Cambridge University Press.

Chapman, J. C. 1992. Social Power in the Iron Gates Mesolithic, in J. Chapman and P. Dolukhanov (eds.), Cultural Transformations and Interactions in Eastern Europe: pp. 71-121. Aldershot: Avebury.

Cook, G., C. Bonsall, R. E. M. Hedges, K. McSweeney, V. Boroneant, L. Bartosiewicz \& P. B. Pеттітt, 2002. Problems of dating human bones from the Iron Gates. Antiquity 76: 77-85.

Demoule, J-P. \& M. Lichardus-Itten. 1994. Fouilles Franco-Bulgares du site neolithique ancien de Kovacevo (Bulgarie du sud-ouest). Rapport préliminaire (campagnes 1986-1993). Bulletin de corespondance helenique 118 (1994). 2 Études Chroniques et rapports: 561-618.

ČuljKović, B., S. Stefanović, \& S. Romac. in press. DNA-based sex identification of the infant remains from Lepenski Vir, in C. Bonsall et al.

Gallis, K. 1996. Burial customs, in G. A. Papathanassopoulos (ed.), Neolithic Culture in Greece: pp. 171-4. Athens: Nicholas P. Goulandris Foundation, Museum of Cycladic Art.

Garašanin, M. \& I. Radovanović. 2001. A pot in house 54 at Lepenski Vir I. Antiquity 75(287): 118-125.

GiBSON, T. 1995. Having your house and eating it: houses and siblings in Ara, south Sulawesi, in J. Carsten \& S. Hugh-Jones (eds.): pp. 129-48.

Gillespie, S. D. 2000. Maya "Nested Houses": The Ritual Construction of Place, in R. A. Joyce \& S. D. Gillespie: pp. 133-60. 


\section{Dusan Borić \& Sofija Stefanović}

Gimbutas, M. (ed.). 1976. Neolithic Macedonia: as reflected by excavation at Anza, southeast Yugoslavia. Los Angeles: The Institute of Archaeology, University of California at Los Angeles.

Grupe, G., H. Manhart, Ž. Mikić \& J. Peters, 2003. Vertebrate food webs subsistence strategies of Meso- and Neolithic populations of central Europe, in G. Grupe \& J. Peters (ed.) Documenta Archaeobilogiae 1. Yearbook of the State Collection of Anthropology and Palaeoanatomy, München, Germany: pp. 193-213. Rahden/Westf.: Verlag M. Leidorf.

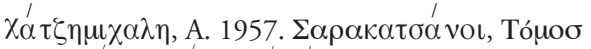
$\pi \rho \omega \pi о \sigma, \mu \varepsilon \rho о \sigma \mathrm{A}, \mathrm{B}, \mathrm{A} \theta \eta v \alpha \mathrm{l}$.

Hawkes, L. with T. Molleson. 2000. Reflashing the Past, in I. Hodder (ed.), Towards reflexive method in archaeology: the example of Çatalhöyük: pp. 153-66. Cambridge: McDonald Institute for Archaeological Research.

Hodder, I. 1990. The Domestication of Europe. Structure and Contingency in Neolithic Societies. Oxford: Basil Blackwell.

-1999. Symbolism at Çatalhöyük, in J. Coles, R. Benley \& P. Mellars (eds.), World Prehistory. Studies in Memory of Grahame Clark: pp. 177-191. Oxford: Oxford University Press.

JACOBSEN, T. W. 1976. 17,000 Years of Greek Prehistory, in Hunters, Farmers and Civilizations: Old World Archaeology. Readings from Scientific American: pp. 133-151. San Francisco: W. H. Freeman and Company.

Joyce, R. A. 2000. Girling the girl and boying the boy: the production of adulthood in ancient Mesoamerica. World Archaeology 31(3): 423-41.

Joyce, R. A. \& S.D. Gillespie. (eds.). 2000. Beyond Kinship. Social and Material Reproduction in House Societies. University of Pennsylvania Press, Philadelphia.

MAYs, S. 1998. The archaeology of human bones. London \& New York: Routledge.

MellaArT, J. 1967. Çatal Hüyük: A Neolithic Town in Anatolia. London: Thames \& Hudson.

Meskell, L. 1994. Dying Young: The Experience of Death at Deir el Medina. Archaeological Review from Cambridge 13(2): 35-45.

-1996. The Somatization of Archaeology: Institutions, Discourses, Corporeality. Norwegian Archaeological Review 29(1): 1-16.

Metcalf, P. \& R. Huntington. 1991. Celebrations of Death. The Anthropology of Mortuary Ritual. Cambridge: Cambridge University Press.

NemesKéRI, J. 1972. The inhabitants of Lepenski Vir, in D. Srejović 1972: pp. 190-204.
-1978. Demographic structure of the Vlasac Epipalaeolithic population, in M. Garašanin (ed.), Vlasac - mezolitsko naselje u Djerdapu (II): pp. 97133. Beograd: Srpska akademija nauka i umetnosti.

Politis, G. G. 1999. La actividad infantil en la producción del registro arqueológico de CazadoresRecolectores. Revista do Museu de Arqueologia e Etnologia Suplemento 3: 263-83.

Radovanović, I. 1996. The Iron Gates Mesolithic. International Monographs in Prehistory. Ann Arbor: Archaeological Series 11.

-1997. The Lepenski Vir Culture: a contribution to interpretation of its ideological aspects, in Antidoron Dragoslavo Srejović completis LXV annis ab amicis collegis discipulis oblatum: pp. 85-93. Beograd: Centar za arheološka istraživanja, Filozofski fakultet.

-2000 . Houses and burials at Lepenski Vir. European Journal of Archaeology 3(3): 330-349.

Roberts, C. \& K. Manchester. 1995. The Archaeology of Disease. New York: Ithaca.

Rodden, R. J. 1965. An Early Neolithic Village in Greece, in Avenues to Antiquity. Readings from Scientific American: pp. 151-59. San Francisco: W. H. Freeman and Company.

RoKSANDIc, M. 1999. Transition from Mesolithic to Neolithic in the Iron Gates gorge: Physical anthropology perspective. Unpublished Ph.D. dissertation, Department of Anthropology, Simon Fraser University, Vancouver.

-2000. Between Foragers and Farmers in the Iron Gates Gorge: Physical Anthropology Perspective. Djerdap Population in Transition from Mesolithic to Neolithic. Documenta Praehistorica 27: 1-100.

RIVIÈRE, P. 1995. Houses, places and people: community and continuity in Guiana, in J. Carsten \& S. Hugh-Jones (eds.): pp. 189-205. Cambridge: Cambridge University Press.

Schrire, C. \& W. L. Steiger. 1974. A matter of life and death: an investigation into the practices of female infanticide in the Arctic. Man (n.s.) 9: 161184.

SсOTT, E. 1999. The Archaeology of Infancy and Infant Death. Oxford: Archaeopress (BAR International Series 819).

SofAEr DereVEnSKI, J. 1997. Engendering children, engendering archaeology, in J. Moore \& E. Scott (eds.), Invisible people and processes. Writing gender and childhood into European archaeology: pp. 192202. London \& New York: Leicester University Press.

SREJOVIĆ, D. 1969. Lepenski Vir - Nova praistorijska kultura u Podunavlju. Beograd: Srpska književna zadruga. 


\section{Birth and death}

-1969a. The Roots of the Lepenski Vir Culture. Archaeologia Iugoslavica 10:13-21.

-1972. Europe's First Monumental Sculpture: New Discoveries at Lepenski Vir. London: Thames \& Hudson.

-1981. Lepenski Vir: Menschenbilder einer frühen europäischen Kultur. Mainz am Rhein: Verlag Philipp von Zabern.

Srejović, D. \& Z. Letica. 1978. Vlasac. Mezolitsko naselje u Djerdapu (I arheologija). Beograd: Srpska akademija nauka i umetnosti.

Srejović, D. \& Lj. Babović. 1983. Umetnost Lepenskog Vira. Beograd: Jugoslavija.

STEFanović, S. \& D. Borić. in press. The new born infant burials from Lepenski Vir: in pursuit of contextual meanings, in C. Bonsall et al.

Tringham, R. 2000. Southeastern Europe in the transition to agriculture in Europe: bridge, buffer or mosaic, in T.D. Price (ed.), Europe's first farmers: pp. 19-56. Cambridge: Cambridge University Press.
Waterson, R. 1990. The Living House: An Anthropology of Architecture in South-East Asia. Kuala Lumpur \& Singapore: Oxford University Press.

-2000. House, Place, and Memory in Tana Toraja (Indonesia), in R.A. Joyce, \& S.D. Gillespie, pp. 177-88.

Welters, L. (ed.). 1999. Folk Dress in Europe and Anatolia: Beliefs about Protection and Fertility.Oxford/New York: Berg.

Whittle, A., L. Bartosiewicz, D. Borić, P. Pettitt, \& M. Richards, 2002. In the beginning: new radiocarbon dates for the Early Neolithic in northern Serbia and south-east Hungary. Antaeus 25: 63-117.

Zoffmann, Zs. 1983. Prehistorical skeletal remains from Lepenski Vir. Homo 34(3/4): 129-48.

-1988. Human Skeletal Remains from Divostin, in A. McPherron \& D. Srejovi'c(eds.), Divostin and the Neolithic of central Serbia: pp. 447-55. Pittsburgh: University of Pittsburgh. 